\title{
V. J. MAMYSHEV-MONROE
}

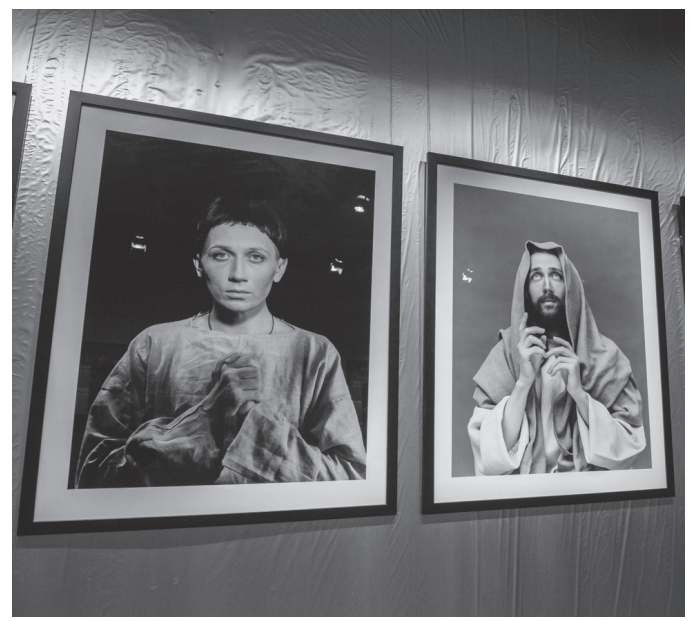

Elää ajassa(an), osallistua aikaan(sa), tehdä ajasta(an) huomioita ja kommentoida - omana itsenään ja omalla itsellään. Näin haluaisin pelkistää vaikutelman, minkä V. J. Mamyshev-Monroen elämän (1969-2013) mittainen taiteellinen tuotanto luo.

Mamyshev-Monroen ura käynnistyi 80-luvun loppuvuosina pietarilaisessa taiteilijayhteisössä. Hän oli taitava piirtäjä, maalari ja installaatiotaiteilija, mutta erityisen merkittävän osan hänen tuotannostaan muodostivat performanssit, videot sekä omakuvat, joissa hän omaksui mitä erilaisimpia rooleja. Marilyn Monroe oli näistä tunnetuin ja pitkäkestoisin.

Mamyshev-Monroe oli esillä Manifesta-näyttelyssä Pietarissa kuluneena kesänä (2014). Päänäyttelyssä oli esillä Monroe-hahmoon keskittyviä videotöitä ja valokuvia. Sen lisäksi Novii Muzei omisti hänen taiteelleen erityisnäyttelyn, johon liittyi kirja The Life of Remarkable Monroe (otsikostaan huolimatta venäjänkielinen); sekä näyttelystä että kirjasta vastasivat Olesja Turkina ja Viktor Mazin. Numeromme kuvat ovat näiden näyttelyiden esittelyaineistoa.

"Merkittävälle Monroelle" omistettu kirja esittää hänen elämänvaiheensa eräänlaisena kehityskertomuksena. Sen juonen muodostaa Mamyshev-Monroen "sankaruus", jonka moniulotteisuutta ilmensivät hänen omaksumansa erilaiset roolit. Kirjassa luodun kertomuksen mukaan"sankaruus"heräsi jo varhain ja ilmeni samastumisena erilaisiin moninaisista lähteistälainattuihin hahmoihin. Tähtikultin ikoni Marilyn Monroe muodostui jo varhain keskeiseksi, mutta tärkeässä asemassa oli myös klassisten neuvostoelokuvien tähti Ljubov Orlova. Toimittajat viittaavat Mamyshevin ja Monroen elämäntarinoiden risteävyyteen - huolimatta siitä, että he elivät täysin eri maailmoissa ja eri aikoina.

Mamyshev-Monroen omakuvissaan omaksumien hahmojen moninaisuuteen sisältyivät muiden muassa Hitler, Kristus, Jeanne d'Arc, Putin, Gorbatšov, Dostojevski, Polonius sekä sarja venäläisen maalaisperinteen naishahmoja. Kuvissa ei ole hitustakaan ulkopuolista ironiaa tai sarkasmia - ne osoittavat, että kuka tahansa meistä voisi olla missä tahansa näistä rooleista.

Mamyshev-Monroen ura ja tuotanto tuovat erityisen selvästi ilmi sen hämmennyksen, jonka naapurimaamme kokema kulttuuris-poliittinen murros tuotti ihmisten identiteetteihin ja asenteisiin. Joskus "sankareille" käy huonosti; teoksen viimeiseen lukuun, "Sankarin kohtalo", sisältyy väliotsikko "Venäjä, jonka me hukkasimme". 